\title{
A PLS -SEM Approach to the UTAUT Model: The Case of Mauritius
}

\author{
Chintamanee Sanmukhiya* \\ Deputy Rector at Modern College in Mauritius, UK
}

Submission: September 21, 2020; Published: October 30, 2020

"Corresponding author: Chintamanee Sanmukhiya, Deputy Rector at Modern College in Mauritius, Royal Road, Central Flacq, Mauritius, UK

Biography

Dr Chintamanee Sanmukhiya completed her PhD in August 2007 at the world's leading institute for social research, Institute of Education, University of London. She has conducted research in different fields such as returns to education, leadership, e-government and labour turnover. She specialises in quantitative and interdisciplinary research. She has published her articles in ISI and SCOPUS-indexed journals. She has presented her research in various prestigious international conferences held in Dubai, Paris, Taiwan, Amsterdam, Malaysia and Singapore. She was Professor and the Head of Academics and Operations at Greenwich University Pakistan (Mauritius Branch). She is Deputy Rector at Modern College in Mauritius.

\section{Abstract}

This study seeks to examine whether the UTAUT model predicts the behavioural intention of Mauritian e-government users. Trust was incorporated into the theoretical framework as a mediator. Data was collected across the island of Mauritius and 141 questionnaires were used for analysis. The SMARTPLS version 3 was used. One formative construct and four reflective constructs were used to measure unobserved factors that affect a citizen's intention to use the government website. The model fits the data well (SRMR $<0.08$ ), has good composite reliability ( $\alpha>0.7)$ and displays adequate convergent validity (AVE $>0.5$ ). Discriminant validity is also obtained (HTMT <0.85) for the reflective constructs. The path coefficient of the redundancy analysis for the formative construct is above 0.8 and there is no multicollinearity problem among the indicators (outer VIF $<5$ ). The exogenous components of the UTAUT model (effort expectancy, facilitating conditions, performance expectancy, social influence) and trust explain around 54\% of the variations in the intention of Mauritian citizens to use the government website. The components of the UTAUT model explain around $37 \%$ of the variations in trust. However, no indirect relationship was revealed but facilitating condition has a direct impact on behavioural intention $(\mathrm{p}<0.001)$. The other components of the UTAUT model do not predict behavioural intention. The impacts of facilitating conditions on trust are greater for men than women. This study shows the case of direct only non-mediation and no effect non mediation, implying that trust does not mediate the relationship between any component of the UTAUT model and its endogenous construct. However, trust affects a citizen's intention to use the Mauritian government website $(p<0.05)$. The impacts of age on the relationships between the predictors and behavioural intention were not established.

The government should devise policies to engender greater trust in its website and whereby Mauritian citizens may experience increasing facilitating conditions. These will ensure the continued use of its website by existing users and they may increase their online activities with the government. These measures will also turn offline users into online users. Increased use of the government website would eventually increase transparency and reduce corruption.

Keywords: Structural Equation Modelling; E-government; Trust; UTAUT

\section{Introduction}

The use of government website contributes to cost effectiveness, reduced monopoly, increase transparency, greater access to government information, high quality of e-government services and reduced corruption. Thus this study uses the Unified Theory of Acceptance and Use of Technology (UTAUT) model to predict citizens' intentions to use the Mauritian government website. It proposes an added component 'trust' as a mediator and direct predictor of a citizen's decision to adopt e-government services. Following the studies of Ali Abdallah Alalwan, Dwivedi \& Rana [1] and Khalilzadeh, Ozturk \& Bilgihan [2], this research adopts the structural equation modelling to examine the adoption of the UTAUT model along with the element of 'trust'. However 
the partial least square structural equation modelling (PLS-SEM) is used instead of the CB-SEM. This paper fundamentally aims to help researchers, academicians and students understand how the PLS-SEM is estimated and interpreted. This study contributes to the existing literature by incorporating the element of trust into the UTAUT model as a predictor to explain the behavioural intention of Mauritian citizens towards the use of the government website. It also investigates whether or not trust can translate effort expectancy, facilitating conditions, performance expectancy and social influence into behavioural intention.

The research objectives may be summarized as follows:

i. To establish the appropriateness of PLS-SEM for UTAUT models

ii. To investigate whether or not trust is a predictor and/or a mediator in the proposed research model

iii. To examine the importance of UTAUT components in predicting the use of government website in Mauritius

iv. To inform government website administrators about the factors that affect citizens' intention to use government websites and enable the former to develop strategies and e-services that would ensure the success of future e-government initiatives.

The rest of this paper is structured as follows: the theoretical framework and a brief empirical review is presented, followed by a throughout examination of the methodology used together with the assessment of the validity and reliability of the constructs used in the research model. The measurement and structural models are further discussed in the next subsection with a critical examination of implications involved. Finally this paper is concluded and some suggestions for further research are proposed.

\section{Literature Review}

As argued by Davis (1989) implementation of IT technology depends on user acceptance. Several models may be used to examine citizens' intentions to use the government website. This research adopts the Unified Theory of Acceptance and Use of Technology (UTAUT) model based on its high popularity among various researchers and due to the fact that this model is a substantial improvement over the others. The UTAUT model was developed by Viswanath. Venkatesh, Morris, Davis, and Davis [3]. This model postulates that use behaviour is predicted by facilitating conditions and behavioural intention. The latter in turn is predicted by performance expectancy, effort expectancy and social influence. The model also includes some moderators such as age, gender, experience and voluntariness of use. Effort expectancy is the ease of using the technology and the extent to which it is not difficult to use and free from effort [4]. Performance expectancy is the extent to which an individual believes that the use of the technology would enable him or her to improve his or her job performance [3]. Social influence, on the other hand, is about the importance attached by the potential user to others' beliefs that he or she should use the new technology. Here others may refer to friends, family, colleagues, leaders or anybody who can influence the potential user through creating awareness, encouragement and information [5]. Facilitating conditions refers to the existence of organisational and technical infrastructures to support the use of the new technology. These may also include specific skills or compatibility with other technologies such as smart phones. Finally the ultimate endogenous factor in the UTAUT model 'behavioural intention' is perceived likelihood that an individual would engage in the given behaviour. It is believed to influence both the actual usage and adoption of the new technology.

Numerous studies have pointed out the importance of trust in terms of online privacy and security to predict the use of e-government [7-11]. In the absence of trust, some citizens would refuse to do online transactions with the government and would only use the website to look up for information, send queries and download application forms. High perceived risks associated with the use of the government website result in non-adoption of e-government services. The latent variable 'trust' for example may refer to trust in the government, trust in government departments and trust in the government website. There are many privacy and security issues associated with online government services which affect the users' decisions to transact online with the government and thus, the latent variable 'behavioural intention'. Hence in this research it is argued that the predictors in the UTAUT model (EE, FC, PE and SI) would not only translate directly into citizens' intentions to use but these would be mediated by trust. Mediators explain how or why an input is translated into an output.

Several studies used the structural equation modelling where they applied the UTAUT model to estimate, for instance, e-management learning system, e-government services, mobile learning, consumer acceptance, mobile learning [12-16]. These were based on PLS-SEM and CBSEM.

\section{Methodology}

Initially a pilot study was conducted among 15 citizens to ensure that all items were properly understood and there was no confusion. The questionnaire was modified accordingly and distributed among 200 citizens. They volunteered to participate in this survey and who were already using the government website. The questionnaires were distributed randomly across the island of Mauritius, for example in Ebene, Grand Bay, Port Louis, Flacq, Rose Belle and Phoenix. However data from 141 questionnaires only could be retained due to missing data. Each questionnaire consisted of 42 questions based on a Likert scale of the 5 point system (strongly disagree, disagree, neutral, agree, strongly agree). One of the constructs (facilitating conditions) was designed to be measured formatively and hence the questionnaire contained an item to capture the overall perception of users on facilitating conditions so as to test for convergent validity. The PLS-SEM approach seemed appropriate to the nature of analysis 


\section{Annals of Social Sciences \& Management studies}

being carried out and due to the small sample size. The SMARTPLS version 3 was used. Some items were eliminated from each constructs due to low loadings (for the reflective constructs) and/ or insignificant weights (for the formative construct). Only items with indicator reliability exceeding 0.4 [17] and weights exceeding 0.1 combined with loadings exceeding 0.5 (if the weights were statistically insignificant or if the confidence interval included zero) with the correct signs, were retained for further analysis [1827]. However, it must be pointed out that deletion of an indicator from a formative construct may change the whole meaning of the latent variable in question. But this study did not face this problem. Table 1 displays all items used for further analysis in this study and Figure 1 illustrates the research model.

Table 1: Items retained for further analysis.

\begin{tabular}{|c|c|c|}
\hline \multicolumn{2}{|l|}{ Latent constructs } & Items on questionnaire \\
\hline \multirow{3}{*}{ Effort expectancy } & EE1 & The website is easy to use \\
\hline & EE2 & It can get whatever I am looking for \\
\hline & EE3 & The website is comprehensible \\
\hline Facilitating conditions & FC1 & Access to internet is not expensive \\
\hline \multirow{2}{*}{ (Formative construct) } & $\mathrm{FC} 2$ & I am confident that I can use the website \\
\hline & FC3 & I have the required knowledge to use the website \\
\hline Overall indicator for facilitating conditions & FC4 & I have all the facilities to use the website \\
\hline \multirow{3}{*}{ Performance expectancy } & PE1 & I usually accomplish my tasks through the website \\
\hline & PE2 & The website provides the services I need \\
\hline & PE3 & The website is useful \\
\hline \multirow{3}{*}{ Social influence } & SC1 & Those who are important to me, think that I must use the website \\
\hline & SC2 & Those who influence me, feel that I must use the website \\
\hline & $\mathrm{SC} 3$ & Those whose opinions matter to me, tell me to use the website \\
\hline \multirow{3}{*}{ Trust } & $\mathrm{T} 1$ & I have trust in government agencies \\
\hline & $\mathrm{T} 2$ & I trust the government website \\
\hline & T3 & I can disclose my personal information on the website \\
\hline \multirow{2}{*}{ Behavioural intention } & BI1 & I predict that I would use the website in the future \\
\hline & $\mathrm{BI} 2$ & I want to continue to use the website \\
\hline
\end{tabular}

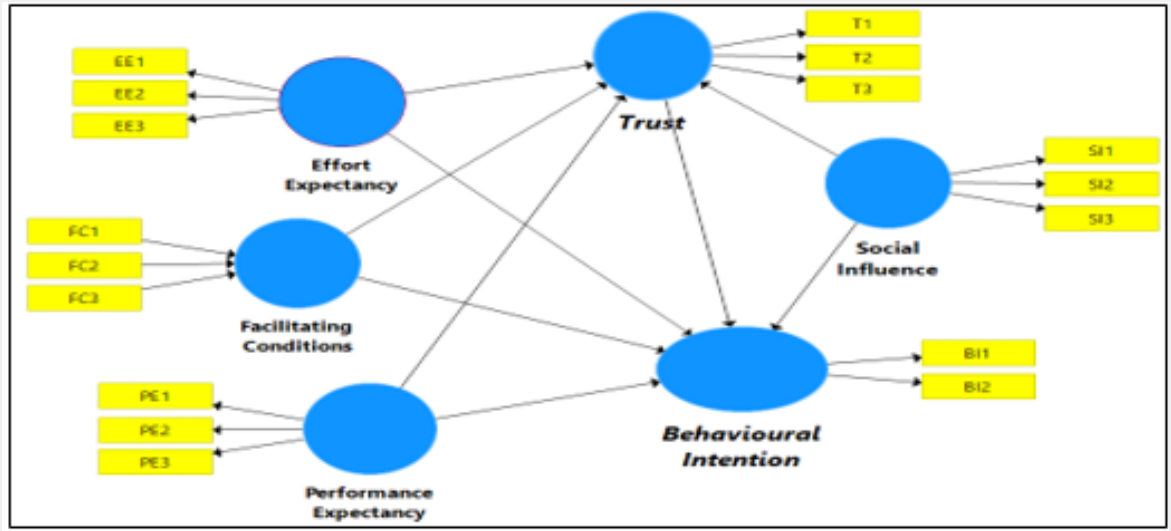

Figure 1: Proposed research model. 


\section{Assessment of the formative construct}

An extensive literature review was undertaken to ensure that the major components of facilitating conditions were included in this construct, thus leading to content validity of the formative construct. This research also establishes convergent validity for the formative construct 'facilitating conditions'. A redundancy analysis was carried out where the formative construct was hypothesized to predict a single item endogenous reflective constructs. As recommended by Joseph F Hair, Ringle \& Sarstedt [28] the path coefficient exceeded the minimum value of 0.8 .
This is illustrated in Figure 2. All weights of indicators within the formatively measured construct are statistically significant at $0.1 \%$ level. As displayed in Table 2, the formatively measured construct does not suffer from the problem of indicator collinearity. The VIF values of the indicators within the 'facilitating conditions' construct do not exceed 5, implying that these indicators are not highly correlated to each other. Table 2 shows very low VIF values and according to Diamantopoulos and Siguaw [29] VIF values less than 3.3 indicates the absence of multicollinearity.

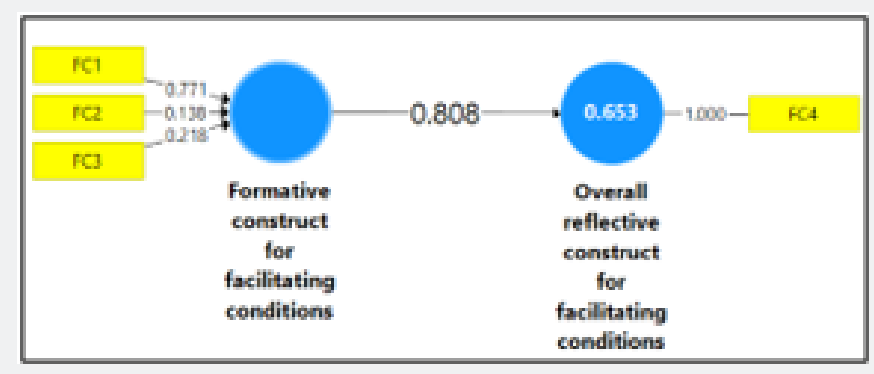

Figure 2: Redundancy Analysis.

Table 2: Collinearity Analysis.

\begin{tabular}{|c|c|}
\hline Facilitating conditions & VIF values \\
\hline FC1 & 1.056 \\
\hline FC2 & 1.011 \\
\hline FC3 & 1.046 \\
\hline
\end{tabular}

\section{Assessment of the reflective constructs}

The reflectively measured constructs (EE, PE, SI and Trust) were also examined in terms of indicator reliability, composite reliability, convergent validity and discriminant validity. Reflective indicators are interchangeable and may thus easily be deleted in case of low outer loadings, that is, when the indicator fails to achieve an indicator reliability value of 0.7 or higher but a value of at least 0.4 may be accepted in case of exploratory research. As can be seen from Figure 3, all loadings of each reflective construct are statistically significant at $0.1 \%$ level. They are either close to 0.8 or higher, indicating that squaring these values would demonstrate high indicator reliabilities. As shown in Table 3, all reflective constructs show high internal consistency reliabilities given that the composite reliability coefficients of each construct exceed 0.8. It is important to point out that for PLS-SEM, composite reliability is usually preferred instead of Cronbach alpha [25]. Convergent validity is also ensured as the AVE values exceed the bare requirement of AVE exceeding 0.5 . In this study each latent variable is capturing at least around $70 \%$ of the variations that it seeks to represent. Discriminant validity was also assessed through the Fornell \& Larcker [30] criteria, Heterotrait-Monotrait (HTMT) ratio and cross loadings [31]. An examination of cross loadings showed that each indicator had the highest loadings in the construct that it was initially supposed to measure. Also none of the correlations among the reflective constructs exceeded the square root of the AVE of each construct. Thus the requirement of Fornell \& Larcker [30] was satisfied. But since HTMT values are deemed to be more accurate for PLS-SEM, only these are reported in Table 4. None of the latent variable display HTMT values above 0.85 , implying that the reflective constructs are sufficiently distinct from one another. Given that all conditions for formatively and reflectively measured constructs have been met, it may be concluded that these constructs may be used to estimate the impacts of EE, FC, PE, SI and Trust on the behavioural intention of Mauritian citizens to use the government website.

Table 3: Construct reliability and validity.

\begin{tabular}{|c|c|c|}
\hline Constructs & Composite Reliability & Average Variance Extracted (AVE) \\
\hline Behavioural Intention & 0.825 & 0.703 \\
\hline Effort Expectancy & 0.872 & 0.695 \\
\hline Performance Expectancy & 0.875 & 0.7 \\
\hline Social Influence & 0.888 & 0.726 \\
\hline Trust & 0.904 & 0.759 \\
\hline
\end{tabular}


Annals of Social Sciences \& Management studies

Table 4: Divergent validity: Heterotrait-Monotrait (HTMT) ratios.

\begin{tabular}{|c|c|c|c|c|}
\hline & Behavioural Intention & Effort Expectancy & Performance Expectancy & Social Influence \\
\hline Effort Expectancy & 0.425 & & & \\
\hline Performance Expectancy & 0.381 & 0.742 & & \\
\hline Social Influence & 0.302 & 0.251 & 0.234 & \\
\hline Trust & 0.629 & 0.55 & 0.523 & 0.473 \\
\hline
\end{tabular}

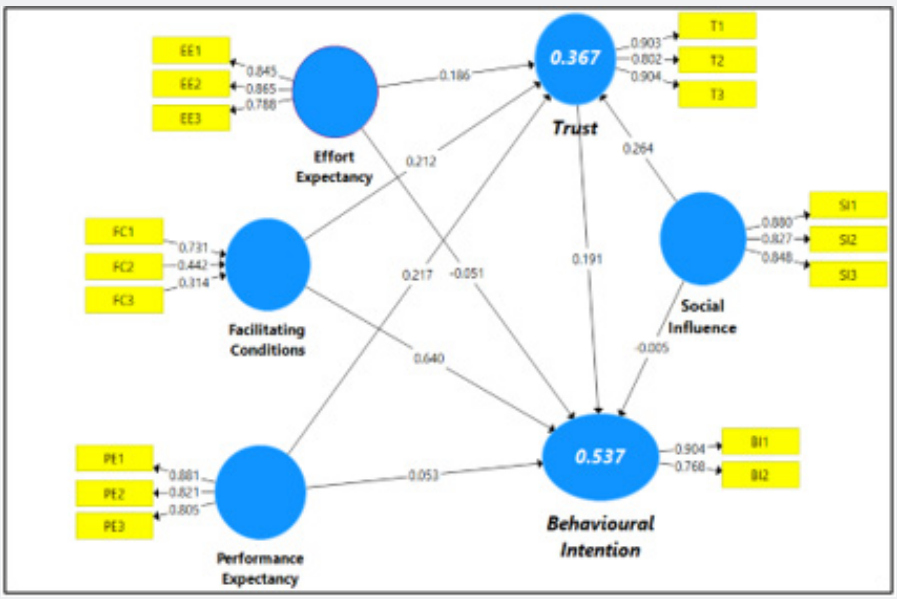

Figure 3: Outer loadings and path coefficients.

\section{Analysis \& Discussions}

The SRMR value of 0.078 indicates good model fit. Following the guidelines provided by Chin [32], Joe F Hair et al. [23] \& Jorg Henseler et al. [26], it may be deduced that the modified UTAUT predictors (EE, FC, PE, SI) has a weak predictive accuracy on Trust $\left(\mathrm{R}^{2}=0.367\right)$. However the inclusion of trust as a predictor of $\mathrm{BI}$ and as the mediator between the UTAUT predictors and BI, yields a model with a moderate predictive accuracy $\left(\mathrm{R}^{2}=0.537\right)$. The analysis stops after only 9 iterations which are much lower than the 300 iterations set as default by the software, thus upholding the model stability. As advocated by Stone [33] and Geisser [34] predictive relevance was assessed through the cross-validated redundancy $Q^{2}$ value exceeding zero. For this study medium predictive relevance for the endogenous variable trust and almost large predictive accuracy for behavioural intention were ensured with $Q^{2}$ values of 0.263 and 0.314 , respectively. However effort expectancy, social influence and trust have not predictive relevance for the construct 'behavioural intention' $\left(q^{2}=0, q^{2}=0.013\right.$ and $\mathrm{q}^{2}=0.003$, respectively) although facilitating conditions and performance expectancy have medium predictive relevance for this construct, $\mathrm{BI}\left(\mathrm{q}^{2}=0.148\right.$ and $\mathrm{q}^{2}=0.154$, respectively). Also all exogenous predictors of the UTAUT model (EE, FC, PE and SI) have small predictive relevance for the endogenous construct 'trust' $\left(\mathrm{q}^{2}=0.02, \mathrm{q}^{2}=0.033, \mathrm{q}^{2}=0.03\right.$ and $\mathrm{q}^{2}=0.058$, respectively).

The path coefficients are displayed in Figure 3 and related statistics are listed in Table 5. All path coefficients linking the four predictors of the UTAUT model to the mediator 'Trust' are statistically significant. Social influence exerts the greatest influence on Trust $(\beta=0.266, p<0.001)$ followed by performance expectancy $(\beta=0.216, p<0.01)$, facilitating conditions $(\beta=0.215$, $\mathrm{p}<0.05)$ and effort expectancy $(\beta=0.186, p<0.05)$. However following Wong [35], it is argued that a standardised path coefficient should exceed 0.20 to establish its importance in the model and relevance to managerial decision. Also given the low $\mathrm{f} 2$ values and as per Cohen [36], it may be stated that these predictors have small effects on producing the $\mathrm{R}^{2}$ value for trust $\left(0.02<\mathrm{f}^{2}<0.15\right)$. Next the effect on the ultimate endogenous construct, $\mathrm{BI}$ is considered. Only facilitating conditions and trust have direct and significant impacts on behavioural intention whereby facilitating conditions have the greatest influence on a citizen's decision to use website $(\beta=0.632, p<0.001)$. As per Cohen [36] it may be deduced that facilitating conditions have large effects on behavioural intention ( $\left.\mathrm{f}^{2}>0.35\right)$. Unlike what supporters of the UTAUT model ultimately advocate, this study concludes that effort expectancy, performance expectancy and social influence have no bearing on citizens' decisions to use the government website $\left(\mathrm{p}>0.05, \mathrm{f}^{2}<0.02\right)$. No relationship between behavioural intention and the other predictors (EE, PE and SI) may point towards the inability of government website administrators to address concerns relating to these predictors and the overall quality of the website. On the other hand, if people perceived greater ease of use, improved performance and receive better comments from existing users, these would ensure an increase in online transactions with the Mauritian government and may convert offline users into online users. 
Table 5: Direct paths and bootstrapping results.

\begin{tabular}{|c|c|c|c|c|c|c|c|}
\hline & \multirow{2}{*}{ Hypothesis } & \multirow{2}{*}{$\begin{array}{l}\text { Direct path } \\
\text { coefficient }\end{array}$} & \multirow{2}{*}{ T value } & \multirow{2}{*}{ P Value } & \multicolumn{2}{|c|}{$\begin{array}{l}\text { Bias corrected confi- } \\
\text { dence intervals }\end{array}$} & \multirow{2}{*}{$\begin{array}{l}\text { Effect size } \\
\text { (f-squared) }\end{array}$} \\
\hline & & & & & Lower & Upper & \\
\hline $\mathrm{H} 1$ & $\begin{array}{l}\text { Effort expectancy will positively affect } \\
\text { behavioural intention of citizens to use the } \\
\text { government website }\end{array}$ & -0.044 & 0.735 & 0.462 & -0.202 & 0.088 & 0.003 \\
\hline $\mathrm{H} 2$ & $\begin{array}{l}\text { Facilitating conditions will positively affect } \\
\text { behavioural intention of citizens to use the } \\
\text { government website }\end{array}$ & 0.632 & 6.992 & 0 & 0.418 & 0.775 & 0.684 \\
\hline H3 & $\begin{array}{l}\text { Performance expectancy will positively } \\
\text { affect behavioural intention of citizens to } \\
\text { use the government website }\end{array}$ & 0.053 & 0.674 & 0.5 & -0.106 & 0.214 & 0.004 \\
\hline $\mathrm{H} 4$ & $\begin{array}{l}\text { Social Influence will positively affect } \\
\text { behavioural intention of citizens to use the } \\
\text { government website }\end{array}$ & -0.007 & 0.097 & 0.923 & -0.15 & 0.123 & 0 \\
\hline H5 & $\begin{array}{l}\text { Trust will positively affect behavioural } \\
\text { intention of citizens to use the government } \\
\text { website }\end{array}$ & 0.188 & 2.435 & 0.015 & 0.037 & 0.352 & 0.05 \\
\hline H6 & $\begin{array}{l}\text { Effort Expectancy will positively affect } \\
\text { citizens' trust }\end{array}$ & 0.186 & 2.041 & 0.041 & 0.014 & 0.377 & 0.033 \\
\hline $\mathrm{H} 7$ & $\begin{array}{l}\text { Facilitating conditions will positively affect } \\
\text { citizens' trust }\end{array}$ & 0.215 & 2.548 & 0.011 & 0.036 & 0.368 & 0.058 \\
\hline H8 & $\begin{array}{l}\text { Performance expectancy will positively } \\
\text { affect citizens' trust }\end{array}$ & 0.216 & 2.606 & 0.009 & 0.054 & 0.379 & 0.049 \\
\hline H9 & $\begin{array}{l}\text { Social Influence will positively affect citi- } \\
\text { zens' trust }\end{array}$ & 0.266 & 4.183 & 0 & 0.129 & 0.38 & 0.1 \\
\hline
\end{tabular}

Trust has a direct but weak effect on behavioural intention $\left(0.02<\mathrm{f}^{2}<0.15\right)$. . Nevertheless trust may be used as a predictor for citizens' intentions to use the Mauritian government website. This research confirms what other studies have reported elsewhere, that is, citizens need to feel that they can trust the government website before they can use it. Besides in many countries e-government initiatives have failed due to insufficient security and privacy assurance. Citizens want the government to protect them against fraud, identity theft and unauthorised access by third party to their personal information $[37,38]$. Online policy statements guaranteeing protections against these, proper online explanation of how personal data of citizens are handled by website administrators and online testimonies by actual citizens can encourage more people to do online transactions with the government. Table 6 shows the results of mediation. It can be deduced that Trust does not act as a mediator between the predictors of the UTAUT model and the endogenous variable, behavioural intention. None of the indirect paths are statistically significant. But since facilitating conditions have significant direct impacts on behavioural intention but no indirect impact, this points towards the case of direct only non-mediation. However there is no effect non-mediation in the cases of performance expectancy, effort expectancy and social influence since both the direct and indirect impacts on behavioural intention are insignificant. These imply that trust does not mediate the relationship between any predictor of the UTAUT model (EE, FC, PE and SI) and its endogenous construct (BI). Multi-group analyses were also done to examine whether the use of government website is influenced by gender or age. Since gender is a nominal variable and age was coded as an ordinal variable, the multi-group analyses were deemed appropriate. This research revealed that men were more willing than women to trust e-government services if facilitating conditions were in place $(\mathrm{p}<0.05)$. This clearly points towards the need for the government to ensure that greater facilitation conditions are made available to male citizens. Simultaneously Mauritian government should find ways on how to increase the level of trust by women. Even though female citizens have the required facilitating conditions, they show lower level of trust in e-government services and hence they will be reluctant to use the government website or even recommend it to others. These would further endanger the use of the Mauritian government website.

Also the relationships between behavioural intention and none of the predictors (EE, FC, PE, SI and trust) were influenced by age. Age therefore does not change the way people perceive ease of use and performance expectancy (Table 7). On top of that age does not influence their level of trust and how they speak about the Mauritian government website to others. In other words, older Mauritian citizens are not different from younger citizens when it comes to explaining how EE, FC, PE, SI and trust influence their intentions to use the website. 
Table 6: Mediation Analysis.

\begin{tabular}{|c|c|c|c|c|}
\hline & Hypothesis & Indirect path coefficient & T value & P value \\
\hline $\mathrm{H} 10$ & $\begin{array}{l}\text { Trust mediates the relationship between effort expectancy and be- } \\
\text { havioural intention }\end{array}$ & 0.034 & 1.554 & 0.12 \\
\hline H11 & $\begin{array}{l}\text { Trust mediates the relationship between facilitating conditions and } \\
\text { behavioural intention }\end{array}$ & 0.04 & 1.745 & 0.081 \\
\hline $\mathrm{H} 12$ & $\begin{array}{l}\text { Trust mediates the relationship between performance expectancy and } \\
\text { behavioural intention }\end{array}$ & 0.041 & 1.696 & 0.09 \\
\hline $\mathrm{H} 13$ & $\begin{array}{c}\text { Trust mediates the relationship between social influence and be- } \\
\text { havioural intention }\end{array}$ & 0.051 & 1.839 & 0.066 \\
\hline
\end{tabular}

Table 7: Multi Group Analysis.

\begin{tabular}{|c|c|c|c|}
\hline & Hypothesis & Path coefficient & P value \\
\hline H14 & $\begin{array}{c}\text { Age affects the relationships between behavioural intention } \\
\text { and each predictor of the research model }\end{array}$ & insignificant & No \\
\hline H15 & $\begin{array}{c}\text { Predictors of the UTAUT model engenders greater trust in the } \\
\text { government website for men than women }\end{array}$ & 0.42 & $\begin{array}{c}\text { Partially yes(applies to facili- } \\
\text { tating conditions and trust) }\end{array}$ \\
\hline
\end{tabular}

\section{Conclusions}

When trust is treated as an endogenous latent variable, it may be deduced that trust is significantly affected by all predictors of the UTAUT model, that is, effort expectancy, facilitating conditions, performance expectancy and social influence. But these predictors exert small effects on trust $\left(0.02<\mathrm{f}^{2}<0.15\right)$. However Trust does not act as a mediator in the UTAUT model. But it may be argued that since a mediator is an internal psychological factor, it is usually measured with error [39] which in turn underestimates the impacts of the mediator (Trust) and may overestimate the impacts of the predictors (EE, FC, PE and SI) on the dependent variable (BI). Age does not affect the relationship between behavioural intention and citizens' perceptions of EE, FC, PE, SI and trust. However men are more willing than women to trust e-government services if they have facilitating conditions to use the government website. Since customers are primarily motivated through the advantages and usefulness associated with the use of any new technology [40], the Mauritian government website administrators should look into these aspects if they want to maintain existing users and attract new users. Constant strengthening of the aspects related to facilitating conditions and trust will safeguard the continued use of the government website by current users. Also as people carry their mobile phones anywhere and anytime, these may become the eventual converged device [16], so website administrators must ensure that citizens can access all government webpages on their mobile devices.

\section{Suggestions for future research}

This study meets the statistical power requirement of $80 \%$ and thus minimises Type II error. Thus the likelihood of mistakenly rejecting an effect that exists in the population is considerably reduced. The sample size is more than the ten rules requirement advocated by [23]. The maximum number of links pointing at a construct is 5 and thus the required minimum sample size is only
50 but in this study, data was collected from 141 citizens. However Kock \& Hadaya [41] recommends the inverse square root method to get safe and precise estimates. Thus researchers are advised to conduct similar studies on a large scale with this method. The latent variable 'trust' does not mediate the relationship as was initially proposed in this research, suggesting that the theoretical framework is flawed. Future researchers can investigate into the existence of some other unobserved latent variable that may translate performance expectancy, effort expectancy and social influence into citizens' intentions to use the government website. Also future research should include other variables such as system flexibility and quality into the UTAUT model to explain behavioural intention [42-44].

\section{Acknowledgements}

i. I wish to thank the SmartPLS Team for providing me with a license key for an extended trial of the SmartPLS software. I strongly recommend the use of this software to students, academics and researchers.

ii. I also thank Miss Jessica Boyroo for collecting a major part of the data.

\section{References}

1. Alalwan AA, Dwivedi YK, Rana NP (2017) Factors Influencing Adoption of Mobile Banking by Jordanian Bank Customers: Extending UTAUT2 with Trust. International Journal of Information Management 37(3): 99-110.

2. Khalilzadeh J, Ozturk AB, Bilgihan A (2017) Security-Related Factors in Extended UTAUT Model for NFC Based Mobile Payment in the Restaurant Industry. Computers in Human Behavior 70: 460-474.

3. Venkatesh V, Morris MG, Davis GB, Davis FD (2003) User acceptance of information technology: toward a unified view. MIS Quarterly 27(3): 425-478.

4. Davis FD (1989) Perceived usefulness, perceived ease of use, and user acceptance of information technology. MIS Quarterly 13(3): 319-340. 


\section{Annals of Social Sciences \& Management studies}

5. Alalwan AA, Rana NP, Dwivedi YK, Lal B, Williams MD (2015) Adoption of Mobile Banking in Jordan: Exploring Demographic Differences on Customers' Perceptions. Paper presented at the Open and Big Data Management and Innovation, Netherlands.

6. Alasem AN (2015) Privacy and E-government in Saudi Arabia. Paper presented at the World Congress on Engineering and Computer Science WCECS

7. Belanger F, Hiller JS, Smith WJ (2002) Trustworthiness in Electronic Commerce: The Role of Privacy, Security, and Site Attributes. Journal of Strategic Information Systems 11(3-4): 245-270.

8. Carter L, Belanger F (2005) The utilization of e-government services: citizen trust, innovation and acceptance factors. Information Systems Journal 15(1): 5-25.

9. Esichaikul V, Kamal M, Rehman M (2012) Factors influencing e-government adoption in Pakistan. Transforming Government People Process and Policy 6(3): 258-282.

10. Sanmukhiya C (2019a) E-Governance Dimensions in the Republic of Mauritius. Humanities \& Social Sciences Reviews 7(5): 264-279.

11. Tolbert CJ, Mossberger K (2006) The effects of e-government on trust and confidence in government. Public Administration Review 66(3): 354-369.

12. Alrawashdeh TA, Muhairat MI, Alqatawnah SM (2012) Factors Affecting Acceptance of Web-Based Training System: Using Extended UTAUT and Structural Equation Modelling. International Journal of Computer Science 2(2): 156-162.

13. Alshehri M, Drew S, Alhussain T, Alghamdi R (2012) The Effects of Web-site Quality on Adoption of E-Government Service: An Empirical Study Applying UTAUT Model Using SEM Paper presented at the $23^{\text {rd }}$ Australasian Conference On Information Systems, Geelong.

14. Chao C-M (2019) Factors Determining the Behavioral Intention to Use Mobile Learning: An Application and Extension of the UTAUT Model. Frontiers in Psychology 10: 1-14.

15. Nichoas-Omoregbe OS, Azeta AA, Chiazor IA, Omoregbe N (2017) Predicting the Adoption of E-Learning Management System: A Case of Selected Private Universities in Nigeria. Turkish Online Journal of Distance Education 18(2): 106-121

16. Saleh A, Václav S (2013) Consumers' Acceptance and Use of Information and Communications Technology: A UTAUT and Flow Based Theoretical Model. Journal of Technology Management \& Innovation 8(2): 61-73.

17. Hulland J (1999) Use of Partial Least Squares (PLS) in Strategic Management Research A Review of Four Recent Studies. Strategic Management Journal 20(2): 195-204.

18. Andreev P, Heart T, Maoz H, Pliskin N (2009) Validating Formative Partial Least Squares (PLS) Models: Methodological Review and Empirical Illustration. Paper presented at the Thirtieth International Conference on Information Systems, Arizona

19. Hair J, Hollingsworth CL, Randolph AB, Chong AYL (2017) An updated and expanded assessment of PLS-SEM in information systems research Industrial Management \& Data Systems 117(3): 442-458.

20. Hair JF, Black WC, Babin BJ, Anderson RE (2010) Multivariate Data Analysis. Upper Saddle River, NJ Prentice Hall.

21. Hair JF, Hult TGM, Ringle CM, Sarstedt M (2017) A Primer on Partial Least Squares Structural Equation Modeling (PLS-SEM) ( $\left.2^{\text {nd }} e d n.\right)$, SAGE Publications, Inc, New York.

22. Hair JF, Matthews LM, Matthews RL, Sarstedt M (2017) PLS-SEM or CB-SEM: Updated Guidelines on Which Method to Use International Journal of Multivariate Data Analysis 1(2): 107-122.

23. Hair JF, Ringle CM, Sarstedt M (2011) PLS-SEM: Indeed a silver bullet.
Journal of Marketing Theory and Practice 19(2): 139-151.

24. Hair JF, Risher JJ, Sarstedt M, Ringle CM (2019) When to Use and How to Report the Results of PLS-SEM. European Business Review 31(1): $2-24$.

25. Dijkstra TK, Henseler J (2015) Consistent Partial Least Squares Path Modeling. MIS Quarterly 39(2): 297-316.

26. Henseler J, Ringle CM, Sinkovics RR (2009) The Use of Partial Least Squares Path Modeling in International Marketing. Advances in International Marketing 20: 277-319.

27. Sarstedt M, Ringle CM, Hair JF (2017) Partial Least Squares Structural Equation Modeling. In Homburg C, Klarmann M \& Vomberg A (Eds.), Handbook of Market Research, Springer International Publishing AG, pp. 1-41.

28. Hair JF, Ringle CM, Sarstedt M (2013) Editorial - Partial Least Squares Structural Equation Modeling: Rigorous Applications, Better Results and Higher Acceptance. Long Range Planning 46(1-2): 1-12.

29. Diamantopoulos A, Siguaw JA (2006) Formative Versus Reflective Indicators in Organizational Measure Development: A Comparison and Empirical Illustration. British Journal of Management 17(4): 263-282.

30. Fornell C, Larcker DF (1981) Evaluating Structural Equation Models with Unobservable Variables and Measurement Error. Journal of Marketing Research 18(1): 39-50.

31. Klein R, Rai A (2009) Interfirm Strategic Information Flows in Logistics Supply Chain Relationships. MIS Quarterly 33(4): 735-762.

32. Chin WW (1998) The Partial Least Squares Approach to Structural Equation Modeling. In Marcoulides GA (Edn.), Modern Methods for Business Research. Lawrence Erlbaum Associates, New Jersey, United States.

33. Stone M (1974) Cross-validation Choice and Assessment of Statistical Predictions. Journal of the Royal Statistical Society Series B 36(2): 111147.

34. Geisser S (1975) The Predictive Sample Reuse Method with Applications. Journal of the American Statistical Association 70(350): 320-328.

35. Wong KK-K (2013) Partial Least Square Structural Equation Modeling (PLS-SEM) Techniques Using Smart PLS. Marketing Bulletin 24: 1-32.

36. Cohen J (1988) Statistical Power Analysis for the Behavioral Sciences $\left(2^{\text {nd }}\right.$ Edn.), Lawrence Erlbaum Associates, New York, United States.

37. Al Athmay A A, Fantazy K, Kumar VD (2016) E-government Adoption and User's Satisfaction: An empirical Investigation. EuroMed Journal of Business 11(1): 51-83.

38. Sanmukhiya C (2019b) A Study of EFFect of Demographic Factors on E-Government Divide in The Republic of Mauritius. Humanities \& Social Sciences Reviews 7(6): 436-446.

39. Baron RM, Kenny DA (1986) The Moderator-Mediator Variable Distinction in Social Psychological Research: Conceptual, Strategic, and Statistical Considerations. Journal of Personality and Social Psychology 51(6): 1173-1182.

40. Alalwan AA, Dwivedi YK, Williams MD (2016) Customers' Intention and Adoption of Telebanking in Jordan. Information Systems Management 33(2): 154-178.

41. Kock N, Hadaya P (2018) Minimum Sample Size Estimation in PLSSEM: The Inverse Square Root and Gamma-Exponential Methods. Information Systems Journal 28(1): 227-261.

42. Hair JF, Ringle CM, Sarstedt M (2012) Partial Least Squares: The Better Approach to Structural Equation Modeling. Long Range Planning 45(56): 312-319. 
43. Henseler J, Ringle CM, Sarstedt M (2015) A New Criterion for Assessing Discriminant Validity in Variance-Based Structural Equation Modeling Journal of the Academy of Marketing Science 43(1): 115-135.
44. Venkatesh V, Thong JY L, Xu X (2012) Consumer Acceptance and Use of Information Technology: Extending the Unified Theory of Acceptance and Use of Technology. MIS Quarterly 36(1): 157-178.

DOI: 10.19080/ASM.2020.06.555677

\section{Your next submission with Juniper Publishers will reach you the below assets}

- Quality Editorial service

- Swift Peer Review

- Reprints availability

- E-prints Service

- Manuscript Podcast for convenient understanding

- Global attainment for your research

- Manuscript accessibility in different formats

( Pdf, E-pub, Full Text, Audio)

- Unceasing customer service

Track the below URL for one-step submission https://juniperpublishers.com/online-submission.php 